\title{
PENGARUH RETURN ON ASSETS DAN DEBT TO EQUITY RATIO TERHADAP HARGA SAHAM PADA INSTITUSI FINANSIAL DI BURSA EFEK INDONESIA
}

\author{
Rani Ramdhani \\ Management Department, School of Business Management, Binus University \\ Jln. K.H. Syahdan No. 9, Palmerah, Jakarta Barat 11480 \\ rani.s_ramdhani@ymail.com
}

\begin{abstract}
This study aims to determine the effect of Return on Assets and Debt to Equity Ratio of Stock Price on Financial Institutions in Indonesia Stock Exchange. This study used secondary data, with samples 2 financial companies in Indonesia Stock Exchange during the study period 2004-2010. Independent variables in this study are Return on Assets and Debt to Equity Ratio. This study used purposive sampling technique. The method of data analysis used classical assumption test, hypothesis test, multiple regression analysis, the $F$ test and t test. Based on results of the study, Return on Assets and Debt to Equity Ratio have no significant effect on stock price. Meanwhile, the F test result shows that Return on Assets and Debt to Equity Ratio jointly have no effect on stock price.
\end{abstract}

Keywords: return on assets, debt to equity ratio, stock price

\begin{abstract}
ABSTRAK
Penelitian ini bertujuan untuk mengetahui pengaruh Return on Assets dan Debt to Equity Ratio terhadap Harga Saham pada Institusi Finansial di Bursa Efek Indonesia. Penelitian ini menggunakan data sekunder. Sampel yang digunakan adalah 2 perusahaan finansial di Bursa Efek Indonesia selama periode penelitian 2004-2010. Variabel bebas dalam penelitian ini adalah Return on Assets dan Debt to Equity Ratio. Pengambilan sampel dalam penelitian ini menggunakan teknik purposive sampling. Metode analisis data yang digunakan adalah uji asumsi klasik, pengujian hipotesis, multiple regression analysis, uji $F$ dan uji $t$. Berdasarkan hasil penelitian ini diketahui bahwa Return on Asset dan Debt to Equity Ratio tidak memiliki pengaruh yang signifikan terhadap Harga Saham. Hasil uji F menunjukkan bahwa Return on Asset dan Debt to Equity Ratio secara bersama-sama tidak memiliki pengaruh terhadap Harga Saham.
\end{abstract}

Kata kunci: return on assets, debt to equity ratio, harga saham 


\section{PENDAHULUAN}

Pada dasarnya setiap perusahaan akan selalu membutuhkan modal untuk pertumbuhan perusahaan. Hal ini disebabkan untuk memenuhi kelangsungan hidup perusahaan. Maka dari itu, untuk mempermudah perusahaan dalam mendapatkan modal, terdapat pasar modal yang merupakan tempat para investor dan emiten bertemu untuk melakukan transaksi jual beli saham. Untuk memenuhi kebutuhan dana tersebut, saat ini makin banyak orang yang mendirikan suatu lembaga pembiayaan yang bergerak di bidang penyediaan dana atau barang yang akan dipergunakan oleh pihak lain di dalam mengembangkan usahanya. Saat ini, leasing merupakan salah satu cara perusahaan memperoleh aset atau kepemilikan tanpa harus melalui proses yang berkepanjangan. Semuanya telah diatur oleh perusahaan leasing yang disediakan oleh berbagai perusahaan. Leasing juga merupakan salah satu langkah penghindaran risiko tinggi yang saat ini sudah disadari oleh para pengusaha yang ada.

Kemampuan perusahaan untuk menghasilkan keuntungan dan menilai apakah perusahaan efisien dalam memanfaatkan aktivanya dalam kegiatan operasional perusahaan dapat dilihat dari Return on Assets (ROA). Menurut Weston dan Copeland (1999) hasil pengembalian atas total aktiva (ROA) mencoba mengukur efektivitas perusahaan dalam memanfaatkan seluruh sumber dayanya, yang kadang-kadang disebut dengan hasil pengembalian atas investasi. Hasil pengembalian investasi atau lebih dikenal dengan nama return on investment (ROI) atau return on total assets merupakan rasio yang menunjukkan hasil (return) atas jumlah aktiva yang digunakan dalam perusahaan (Kasmir, 2008).

Debt to Equity Ratio (DER) menunjukkan bagaimana komposisi pendanaan sendiri atau memanfaatkan utang-utangnya, makin besar DER makin besar risiko perusahaan. Menurut Kasmir (2008), Debt to Equity Ratio merupakan rasio yang digunakan untuk menilai utang dengan ekuitas. Rasio ini berguna untuk mengetahui jumlah dana yang disediakan peminjam (kreditor) dengan pemilik perusahaan. Rasio ini dapat melihat seberapa jauh perusahaan dibiayai oleh utang atau pihak luar dengan kemampuan perusahaan yang digambarkan oleh modal (Harahap, 2010).

Penelitian mengenai pengaruh hubungan antara Return On Assets (ROA) terhadap harga saham sudah banyak dilakukan para ahli sebelumnya. Wulandari (2009) dalam penelitiannya menunjukkan variabel ROA secara parsial berpengaruh positif dan signifikan terhadap harga saham. Hasil penelitian ini juga didukung Kusumawardani (2010). Namun hasil penelitian tersebut bertentangan dengan hasil penelitian yang dilakukan oleh Subiyantoro dan Andreani (2003), bahwa Return On Assets (ROA) tidak terdapat pengaruh signifikan terhadap harga saham. Hasil riset tersebut didukung oleh Sasongko dan Wulandari (2006), Anastasia (2003), dan Stella (2009).

Selanjutnya, penelitian mengenai pengaruh Debt to Equity Ratio terhadap harga saham telah banyak dilakukan oleh para ahli sebelumnya. Stella (2009) menyatakan bahwa Debt to Equity Ratio berpengaruh negatif dan signifikan terhadap harga saham. Akan tetapi, hasil penelitian ini bertentangan dengan penelitian yang dilakukan oleh Anastasia (2003). Penelitiannya menyatakan bahwa Debt to Equity Ratio (DER) tidak terdapat pengaruh signifikan terhadapharga saham. Penelitian ini juga didukung oleh Subiyantoro dan Andreani (2003).

Dengan melihat data awal yang berkaitan dengan hubungan Return On Assets (ROA) dan Debt to Equity Ratio (DER) terhadap harga saham terdapat fenomena gap. Terdapat indikasi kenaikkan harga saham pada sektor institusi finansial pada saat return on assets (ROA) menurun dan debt to equity ratio (DER) meningkat. Sehingga ini menjadi masalah karena menurut penelitian yang telah dilakukan Wulandari (2009), variabel ROA secara parsial berpengaruh positif dan signifikan terhadap harga saham. Akan tetapi, fenomena yang terjadi pada sektor institusi finansial adalah adanya 
indikasi Return on Assets (ROA) turun, sedangkan harga saham naik dengan kata lain memiliki hubungan negatif.

Berdasarkan data awal, terdapat fenomena gap dengan indikasi kenaikan harga saham pada sektor institusi finansial pada saat Debt to Equity Ratio (DER) meningkat. Hal ini menjadi masalah karena menurut penelitian yang telah dilakukan Stella (2009) dinyatakan bahwa Debt to Equity Ratio berpengaruh negatif dan signifikan terhadap harga saham. Akan tetapi, fenomena yang terjadi pada institusi finansial adalah adanya indikasi Debt to Equity Ratio (DER) naik, sedangkan harga saham meningkat; dengan kata lain memiliki hubungan negatif.

Dengan demikian dapat disimpulkan bahwa Return on Assets dan Debt to Equity Ratio dapat membantu para investor untuk mengevaluasi pertumbuhan harga saham masa lalu, sekarang, dan untuk memproyeksi harga saham yang akan datang. Serta berdasarkan penelitian terdahulu membuktikan ada pengaruh antara Return On Assets dan Debt to Equity Ratio terhadap harga saham. Dengan demikian, penelitian ini akan membahas Pengaruh Return On Assets dan Debt to Equity Ratio Terhadap Harga Saham Pada Institusi Finansial Di Bursa Efek Indonesia (BEI).

Rumusan masalah dalam penelitian ini adalah sebagai berikut: (a) bagaimana tingkat ROA pada insititusi finansial tahun 2007-2011; (b) bagaimana tingkat DER pada institusi finansial tahun 2007-2011; (c) bagaimana tingkat harga saham pada institusi finansial 2007-2011; (c) seberapa besar pengaruh ROA (Return On Assets) terhadap Harga Saham?; (d) seberapa besar pengaruh DER (Debt to Equity Ratio)terhadap Harga Saham; dan (e) seberapa besar pengaruh ROA (Return On Assets),dan DER (Debt to Equity Ratio), terhadap Harga Saham. Untuk menghindari makin meluasnya masalah penelitian ini, maka penulis melakukan pembatasan masalah. Adapun pembatasan masalah tersebut antara lain: pertama, penelitian ini hanya menggunakan 2 variabel bebas (ROA dan DER) dan 1 variabel terikat (Harga Saham). Kedua, penelitian ini menggunakan sampel Institusi Finansial yang terdaftar di Bursa Efek Indonesia periode 2007-2011.

\section{Tinjauan Pustaka}

\section{Return on Assets (ROA)}

Menurut Riyadi (2006), Return on Assets adalah rasio profitabilitas yang menunjukkan perbandingan antara laba dengan total aset. Rasio ini menunjukkan tingkat efisiensi pengelolaan aset yang dilakukan oleh yang bersangkutan. Menurut Kasmir (2008), hasil pengembalian investasi atau lebih dikenal dengan nama Return on Investment (ROI) atau Return on Total Assets merupakan rasio yang menunjukkan hasil (return) atas jumlah aktiva yang digunakan dalam perusahaan. Makin kecil (rendah) rasio ini, makin kurang baik. Demikian pula sebaliknya.

Menurut Mardiyanto (2009) ROA adalah rasio yang digunakan untuk mengukur kemampuan perusahaan dalam menghasilkan laba yang berasal dari aktivitas investasi. Rasio ini digunakan untuk mengukur kemampuan manajemen dalam memperoleh keuntungan (laba) secara keseluruhan. Makin besar ROA, makin besar pula tingkat keuntungan yang dicapai oleh perusahaan tersebut dan makin baik pula posisi perusahaan tersebut dari segi penggunaan asset (Dendawijaya, 2003).

Menurut Lestari dan Sugiharto (2007) angka ROA dapat dikatakan baik apabila $>2 \%$. Rasio ini dapat dirumuskan sebagai berikut:

$$
R O A=\frac{\text { Lababersih }}{\text { totalaktiva }} \times 100 \%
$$


Dari beberapa pengertian tersebut dapat disimpulkan bahwa Return on Assets merupakan rasio antara laba setelah pajak terhadap total assets. ROA mencerminkan kemampuan perusahaan dalam memperoleh laba bersih setelah pajak dari total aset yang digunakan untuk operasional perusahaan. Makin tinggi rasio ini menunjukkan bahwa perusahaan makin efektif dalam memanfaatkan aktiva untuk menghasilkan laba bersih setelah pajak.

\section{Debt to Equity Ratio (DER)}

Debt to Equity Ratio merupakan rasio yang digunakan untuk menilai utang dengan ekuitas. Rasio ini dicari dengan cara membandingkan antara seluruh utang, termasuk utang lancar dengan seluruhekuitas. Rasio ini berguna untuk mengetahui jumlah dana yang disediakan peminjam (kreditor) dengan pemilik perusahaan. Dengan kata lain rasio ini berfungsi untuk mengetahui setiap rupiah modal sendiri yang dijadikan jaminan utang.

Bagi bank (kreditor), makin besar rasio ini akan makin tidak menguntungkan karena makin besar resiko yang ditanggung atas kegagalan, namun bagi perusahaan sangat menguntungkan dan sebaliknya. DER untuk setiap perusahaan tentu berbeda-beda, perusahaan dengan arus kas yang stabil biasanya memiliki rasio yang lebih tinggi dari rasio kas yang kurang stabil (Kasmir, 2008).

Menurut Rusdin (2008), rasio Debt to Equity Ratio dapat dirumuskan sebagai berikut:

$$
\mathrm{DER}=\frac{\text { TotalDebt }}{\text { TotalShareholder sEquity }}
$$

\section{Kerangka Pemikiran}

Pada umumnya bentuk informasi yang digunakan oleh para calon investor dan para pemegang saham untuk mengevaluasi kinerja perusahaan dengan menggunakan neraca maupun laporan laba rugi. Harga saham selalu mengalami perubahan. Oleh karena itu, investor harus mampu memperhatikan faktor-faktor yang memengaruhi harga saham tersebut. Harga suatu saham dapat ditentukan menurut hukum permintaan dan penawaran. Makin banyak yang membeli suatu saham, maka harga saham cenderung bergerak naik.

\section{Pengaruh ROA terhadap Harga Saham}

Return on Assets digunakan untuk mengukur efektivitas perusahaan di dalam menghasilkan keuntungan dengan memanfaatkan aktiva yang dimiliki (Kusumawardani, 2010). ROA diperoleh dengan cara membandingkan antara net income after tax (NIAT) terhadap average total asset.

$$
R O A=\frac{\text { Lababersih setelah pajak }}{\text { totalaktiva }}
$$

Makin tinggi return on assets menunjukkan bahwa perusahaan makin efektif dalam memanfaatkan aktiva untuk menghasilkan laba bersih setelah pajak.

\section{Pengaruh DER terhadap Harga Saham}

Debt to Equity Ratio merupakan rasio yang digunakan untuk menilai utang dengan ekuitas. Rasio ini dicari dengan cara membandingkan antara seluruh utang, termasuk utang lancar dengan seluruh ekuitas. Rasio ini berguna untuk mengetahui jumlah dana yang disediakan peminjam (kreditor) dengan pemilik perusahaan. Dengan kata lain rasio ini berfungsi untuk mengetahui setiap rupiah modal sendiri yang dijadikan jaminan utang. (Kasmir,2008) 


$$
\mathrm{DER}=\frac{\text { Total Debt }}{\text { Total Shareholder s Equity }}
$$

Biaya utang lebih kecil daripada dana ekuitas dengan menambahkan utang ke dalam neracanya, perusahaan secara umum dapat meningkatkan profitabilitas yang kemudian menaikkan harga sahamnya, sehingga meningkatkan kesejahteraan para pemegang saham dan membangun potensi pertumbuhan yang lebih besar.

Atas dasar analisis tersebut maka pengaruh dari masing-masing variabel tersebut terhadap harga saham dapat ditunjukkan pada Gambar 1 .

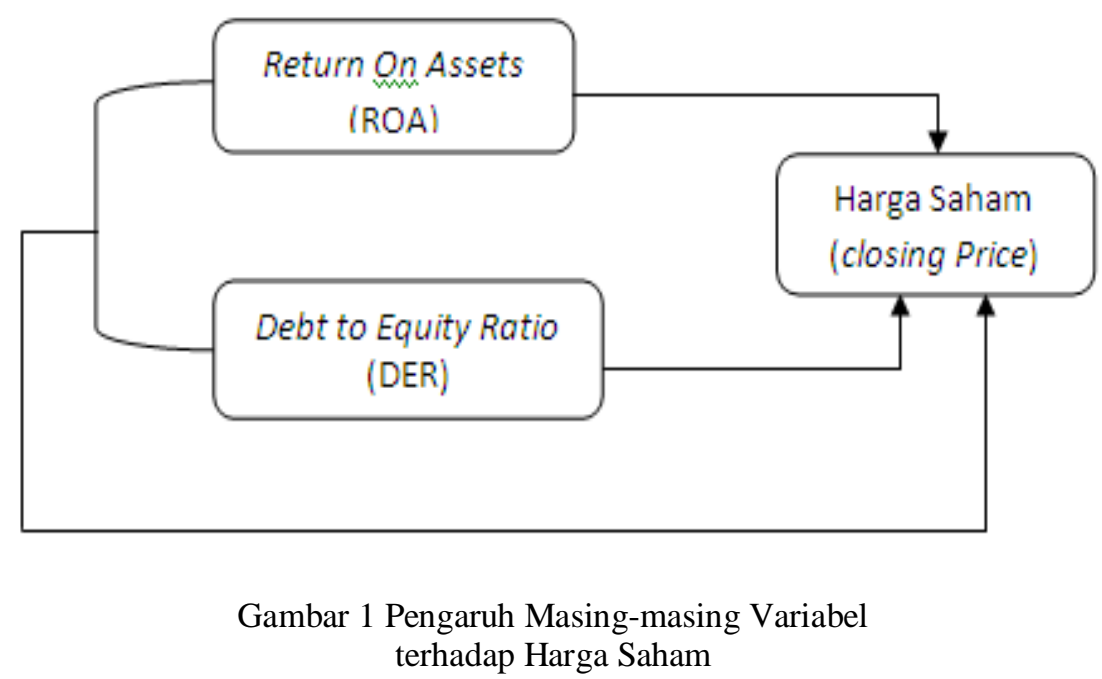

Keterangan :

Variabel penelitian ini terdiri dari dua variabel yaitu variabel dependen dan variabel independent. Variabel dependen dalam hal ini adalah harga saham perusahaan. Variabel independent dalam penelitian ini berupa Return On Asset (ROA) dan Debt to Equity Ratio (DER) sebagai faktor yang memengaruhi harga saham perusahaan.

\section{Hipotesis}

Menurut Ferdinand (2011), hipotesis merupakan jawaban sementara terhadap rumusan masalah penelitian. Berdasarkan kerangka pemikiran yang dikemukakan, penulis merumuskan hipotesis sebagai berikut.

$\mathrm{H}_{1}$ : Return On Asset $\left(\mathrm{X}_{1}\right)$ berpengaruh positif terhadap harga saham $(\mathrm{Y})$ pada Institusi Finansial di Bursa Efek Indonesia.

$\mathrm{H}_{2}$ : Debt to Equity Ratio $\left(\mathrm{X}_{2}\right)$ berpengaruh negatif terhadap harga saham (Y) pada Institusi Finansial di Bursa Efek Indonesia.

$\mathrm{H}_{3}$ : Return On Asset $\left(\mathrm{X}_{1}\right)$, dan Debt to Equity Ratio $\left(\mathrm{X}_{2}\right)$, secara bersama-sama diduga berpengaruh signifikan terhadap harga saham (Y) pada Institusi Finansial di Bursa Efek Indonesia. 


\section{METODE}

Objek penelitian merupakan penjelasan tentang apa dan atau siapa, di mana, dan kapan penelitian dilakukan (Umar, 2004). Oleh karena itu, objek dalam penelitian ini adalah pengaruh Return On Assets (ROA), Debt to Equity Ratio (DER),dan Harga Saham pada Institusi Finansial yang terdaftar di Bursa Efek Indonesia periode 2004-2010. Penelitian ini dilaksanakan di Bursa Efek Indonesia, yang berlokasi di Pusat Referensi Pasar Modal (PRPM) yang beralamat di Jln. Jend.Sudirman Kav.52-53 Tower 2, Jakarta Selatan.

Jenis penelitian yang digunakan dalam penelitian ini adalah jenis penelitian deskriptif dan asosiatif. Penelitian deskriptif adalah penelitian yang dilakukan untuk mengetahui nilai dari suatu variabel, dalam hal ini variabel mandiri, baik satu variabel atau lebih (independent) tanpa membuat perbandingan atau menghubungkan dengan variabel yang lain (Hasan, 2005). Jenis penelitian ini digunakan untuk mengetahui gambaran danmenerangkan keadaan perusahaan yang tergambar melalui laporan keuangan,dalam rangka memperoleh gambaran secara sistematis akan Return On Assets $\left(\mathrm{X}_{1}\right)$, Debt to Equity Ratio $\left(\mathrm{X}_{2}\right)$, dan Harga Saham (Y) yang kemudian diamati perubahan yang terjadi pada ketiga variabel tersebut baik kenaikan atau penurunannya.

Selain menggunakan metode penelitian deskriptif, dalam penelitian ini penulis juga menggunakan metode penelitian asosiatif. Pada penelitian ini metode penelitian asosiatif digunakan untuk mencari pengaruh dari ROA, dan DER terhadap Harga Saham.

Tabel 1 Operasional Variabel

\begin{tabular}{|c|c|c|c|c|}
\hline Variabel & Konsep & Indikator & $\begin{array}{c}\text { Cara } \\
\text { Pengukuran }\end{array}$ & Skala \\
\hline $\begin{array}{l}\mathrm{X}_{1}=\mathrm{ROA}(\text { Return } \\
\text { On Assets) }\end{array}$ & $\begin{array}{l}\text { Kemampuan perusahaan dalam } \\
\text { menghasilkan laba dengan } \\
\text { memanfaatkan total asset } \\
\text { (kekayaan) yang dimiliki oleh } \\
\text { perusahaan. }\end{array}$ & $\begin{array}{l}\text { - } \quad \text { Earnings After Tax } \\
\text { - } \quad \text { Total Assets }\end{array}$ & $\frac{E A T}{\text { Totalaktiva }}$ & Rasio \\
\hline $\begin{array}{l}\mathrm{X}_{2}=\mathrm{DER}(\text { Debt to } \\
\text { Equity Ratio })\end{array}$ & $\begin{array}{l}\text { Kemampuan perusahaan dalam } \\
\text { mengembalikan biaya utang } \\
\text { melalui modal sendiri yang } \\
\text { dimilikinya. }\end{array}$ & $\begin{array}{l}\text { - } \quad \text { Total Liabilites } \\
\text { - Total Equity }\end{array}$ & $\frac{\text { totalhutang }}{\text { totalekuitas }}$ & Rasio \\
\hline $\mathrm{Y}=$ Harga Saham & $\begin{array}{l}\text { Harga suatu saham pada pasar } \\
\text { yang sedang berlangsung }\end{array}$ & - Closing Price & $\frac{\text { jumlahHSpertahun }}{12 \text { bulan }}$ & Rasio \\
\hline
\end{tabular}

Sumber: Pengolahan Penulis

\section{Populasi dan Sampel}

Adapun populasi dalam penelitian ini adalah perusahaan-perusahaan kelompok institusi finansial di Bursa Efek Indonesia periode 2004-2010 dengan data diperoleh dari sumber data sekunder. Sumber data sekunder adalah data-data yang dikumpulkan oleh peneliti melalui pihak kedua atau tangan kedua. Teknik penentuan sampel dalam penelitian ini adalah dengan menggunakan purposive sampling. Teknik ini ditentukan untuk memilih anggota sampel secara khusus berdasarkan tujuan penelitian dan kesesuaian kriteria-kriteria yang telah ditetapkan oleh peneliti.

Adapun kriteria-kriteria dipilihnya anggota populasi menjadi sampel dalam penelitian ini meliputi: perusahaan pada Sektor Institusi Finansial yang telah tercatat di Bursa Efek Indonesia tahun 
2007-2011, perusahaan pada Sektor Institusi Finansial yang menerbitkan laporan keuangan tahunan (annual report) secara kontinu selama lima tahun yaitu sejak tahun 2004 hingga tahun 2010 serta memiliki kelengkapan data terkait dengan variabel-variabel yang dibutuhkan, perusahaan pada Sektor Institusi Finansial yang memiliki laporan tahunan yang berakhir pada 31 Desember, indeks minimum Return On Assets (ROA), Debt to Equity Ratio (DER) dan Harga Saham untuk masing-masing perusahaan harus bernilai positif, data yang digunakan harus memenuhi Uji Asumsi Klasik. Berdasarkan populasi penelitian yang terdiri dari 9 perusahaan, yang memenuhi seluruh kriteria dalam penelitian ini terdapat 2 perusahaan yang dapat diambil sebagai sampel.

\section{HASIL DAN PEMBAHASAN}

Dalam penelitian ini, perusahaan yang menjadi sampel adalah institusi financial yang terdaftar di Bursa Efek Indonesia (BEI) selama periode 2004-2011. Semua data yang diperlukan dalam penelitian ini adalah data sekunder yang berasal dari perusahaan yang go public dan terdaftar di Bursa Efek Indonesia yang meliputi neraca dan laporan rugi/laba maupun data pendukung yang lainnya mulai tahun 2004-2011. Data tersebut diperoleh dari Indonesian Capital Market Directory atau Laporan Keuangan Tahunan Indonesia Stock Exchange (IDX) pada tahun yang bersangkutan dan sampel diperoleh berdasarkan kriteria purposive sampling yang telah ditetapkan. Dari seluruh institusi finansial yang terdaftar di Bursa Efek Indonesia, hanya 8 tahun dan dua sampel perusahaan yang memenuhi kriteria di dalam institusi finansial untuk dilakukan penelitian.

\section{Pengujian Hipotesis}

Dalam penelitian ini kebenaran hipotesis dibuktikan dengan melakukan uji hipotesis dua pihak (two tail test). Pengujian hipotesis bertujuan untuk mengetahui apakah terdapat pengaruh antara Return On Asset dan Debt to Equity Ratio terhadap Harga Saham. Langkah untuk melakukan pengujian hipotesis, yaitu seperti, Uji t dan Uji F sehingga dapat diperoleh hasil jawaban dari hipotesis kerja yang diteliti.

\section{Uji Parsial (Uji t)}

Koefisien ini bertujuan mengukur derajat linier antara variabel $\mathrm{Y}$ dengan sebagian dari variabel-variabel independent jika sebagian dianggap tetap. Menghitung koefisien korelasi parsial antara $\mathrm{X}_{1}$ (ROA) dan Y (Harga Saham), dengan menganggap bahwa $\mathrm{X}_{2}$ (Debt to Equity Ratio) dianggap tetap.

Menurut Ghozali (2006) salah satu cara melakukan uji t adalah dengan membandingkan nilai statistik $\mathrm{t}$ dengan nilai kritis menurut tabel. Jika nilai statistik $\mathrm{t}$ hasil perhitungan lebih tinggi dibandingkan nilai t tabel, hipotesis alternatif yang menyatakan bahwa suatu variabel independent secara individual memengaruhi variabel dependen diterima. Adapun hipotesis secara parsial dalam penelitian ini adalah sebagai berikut:

\section{Hipotesis Pengaruh Return on Asset terhadap Harga Saham}

$\mathrm{Ho}_{1}$ : Return On Asset tidak memiliki pengaruh positif terhadap Harga Saham pada perusahaan Finansial di Bursa Efek Indonesia periode tahun 2004-2010.

$\mathrm{Ha}_{1}$ : Return On Asset memiliki pengaruh positif terhadap Harga Saham pada perusahaan Finansial di Bursa Efek Indonesia periode tahun 2004-2010. 
Tabel 2 Hasil Uji t

Coefficients $^{\mathrm{a}}$

\begin{tabular}{|c|c|c|c|c|c|c|}
\hline & \multirow[t]{2}{*}{ Model } & \multicolumn{2}{|c|}{ Unstandardized Coefficients } & \multirow{2}{*}{$\begin{array}{c}\begin{array}{c}\text { Standardized } \\
\text { Coefficients }\end{array} \\
\text { Beta }\end{array}$} & \multirow[b]{2}{*}{$\mathbf{t}$} & \multirow[b]{2}{*}{ Sig. } \\
\hline & & B & Std. Error & & & \\
\hline \multirow[t]{3}{*}{$\overline{1}$} & (Constant) & 475.411 & 377.791 & & 1.258 & .234 \\
\hline & Roa & -1876.520 & 5052.150 & -.152 & -.371 & .717 \\
\hline & Der & -35.804 & 43.903 & -.334 & -.816 & .432 \\
\hline
\end{tabular}

a. Dependent Variable: hs

Berdasarkan tabel diperoleh $\mathrm{t}_{\text {hitung }}$, maka perbandingan $\mathrm{t}_{\text {tabel }}$ pada taraf kesalahan $\alpha=5 \%$ dengan uji dua arah $(5 \% / 2=0,025)$ dan derajat bebasnya $(\mathrm{df})$ adalah $\mathrm{n}-2=14-2=12$. Dengan menggunakan tabel t-statistik uji dua arah, maka diperoleh $\mathrm{t}_{\text {tabel }}$ sebesar 2,179. Berdasarkan nilai $\mathrm{t}_{\text {hitung }}$ dan $\mathrm{t}_{\text {tabel }}$ variabel independent (ROA) dapat diketahui sebagai berikut. Pengaruh Return on Asset terhadap Harga Saham dalam uji $t$, didapat hasil $t_{\text {hitung }}$ sebesar $-0,371$; sedangkan $t_{\text {tabel }}$ sebesar 2,179. Karena $\mathrm{t}_{\text {hitung }}<\mathrm{t}_{\text {tabel }}(-0.371<2,179)$, dengan demikian $\mathrm{H}_{01}$ diterima.

Artinya, tidak ada pengaruh positif antara ROA terhadap Harga Saham. Ini sesuai dengan penelitiaan yang dilakukan oleh Stella (2009), Subiyantoro dan Andreani (2003) yang menyimpulkan bahwa Return on Asset tidak berpengaruh terhadap Harga Saham. Lebih lanjut, hasil penelitian ini menolak hasil penelitian yang dilakukan oleh Rinati dan Budiman (2009) yang menyimpulkan bahwa Return On Asset memiliki pengaruh yang dominan terhadap Harga Saham.

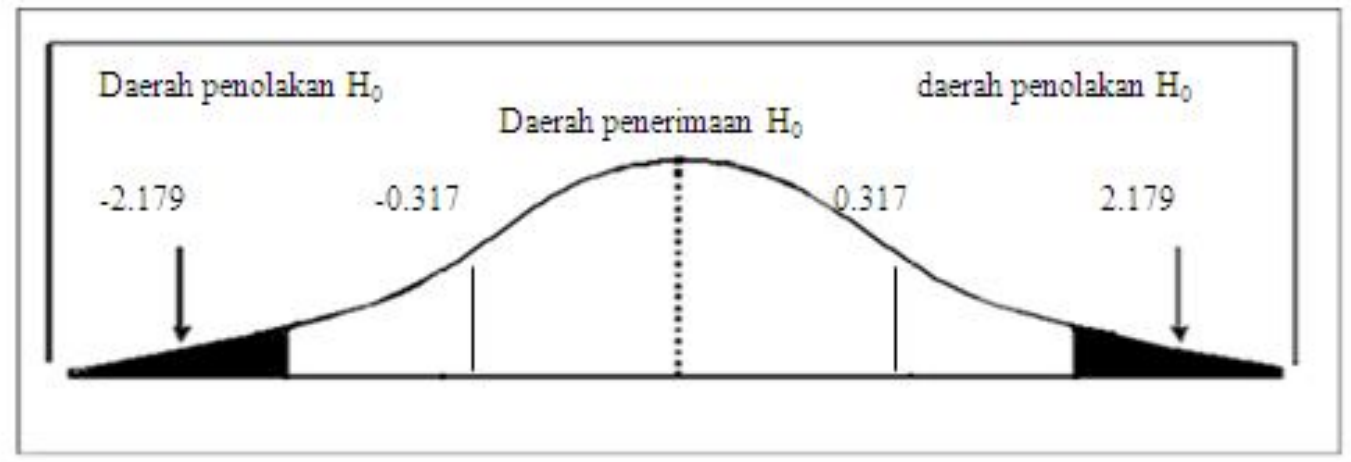

Gambar 2 Kurva Return on Asset terhadap Harga Saham

\section{Hipotesis Pengaruh Debt to Equity Ratio terhadap Harga Saham}

$\mathrm{Ho}_{2}$ : Debt to Equity Ratio tidak memiliki pengaruh negative terhadap Harga Saham pada perusahaan Finansial di Bursa Efek Indonesia periode tahun 2004-2010.

$\mathrm{Ha}_{2}$ : Debt to Equity Ratio memiliki pengaruh negative terhadap Harga Saham pada perusahaan Finansial di Bursa Efek Indonesia periode tahun 2004-2010. 
Tabel 3 Hasil Uji t

Coefficients $^{\mathrm{a}}$

\begin{tabular}{llrrrrr}
\hline \multirow{2}{*}{ Model } & \multicolumn{2}{c}{ Unstandardized Coefficients } & $\begin{array}{c}\text { Standardized } \\
\text { Coefficients }\end{array}$ & & \\
\cline { 3 - 5 } & & \multicolumn{1}{c}{ B } & Std. Error & Beta & t & Sig. \\
\hline 1 & (Constant) & 475.411 & 377.791 & & 1.258 & .234 \\
& Roa & -1876.520 & 5052.150 & -.152 & -.371 & .717 \\
& Der & -35.804 & 43.903 & -.334 & -.816 & .432 \\
\hline
\end{tabular}

a. Dependent Variable: hs

Berdasarkan tabel diperoleh $\mathrm{t}_{\text {hitung }}$ maka kita bandingkan dengan $\mathrm{t}_{\text {tabel }}$ pada taraf kesalahan $\alpha=5 \%$ dengan uji dua arah $(5 \% / 2=0,025)$ dan derajat bebasnya $(\mathrm{df})$ adalah $\mathrm{n}-2=14-2=12$. Dengan menggunakan tabel t-student uji dua arah maka diperoleh $\mathrm{t}_{\text {tabel }}$ sebesar 2,179.Berdasarkan nilai $\mathrm{t}_{\text {hitung }} \mathrm{dan}_{\mathrm{t}}$ tabel variabel independent (DER) dapat diketahui bahwa:

Pengaruh Debt to Equity Ratio terhadap Harga Saham dalam uji t, didapat hasil $\mathrm{t}_{\text {hitung }}$ sebesar 0,816 sedangkan $\mathrm{t}_{\text {tabel }}$ sebesar 2,179. Karena $\mathrm{t}_{\text {hitung }}<\mathrm{t}_{\text {tabel }}(-0.816<2,179)$, dengan demikian $\mathrm{H}_{02}$ diterima yang artinya bahwa tidak memiliki pengaruh negatif antara DER terhadap Harga Saham. Ini sesuai dengan penelitiaan yang dilakukan oleh Anastasia (2003), Subiyantoro dan Andreani (2003) yang menyimpulkan bahwa Debt to Equity Ratio tidak berpengaruh terhadap Harga Saham. Namun hasil penelitian ini menolak hasil penelitian yang dilakukan oleh Kusumawardani (2010) yang menyimpulkan bahwa Debt to Equity Ratio memiliki pengaruh yang signifikan terhadap Harga Saham.

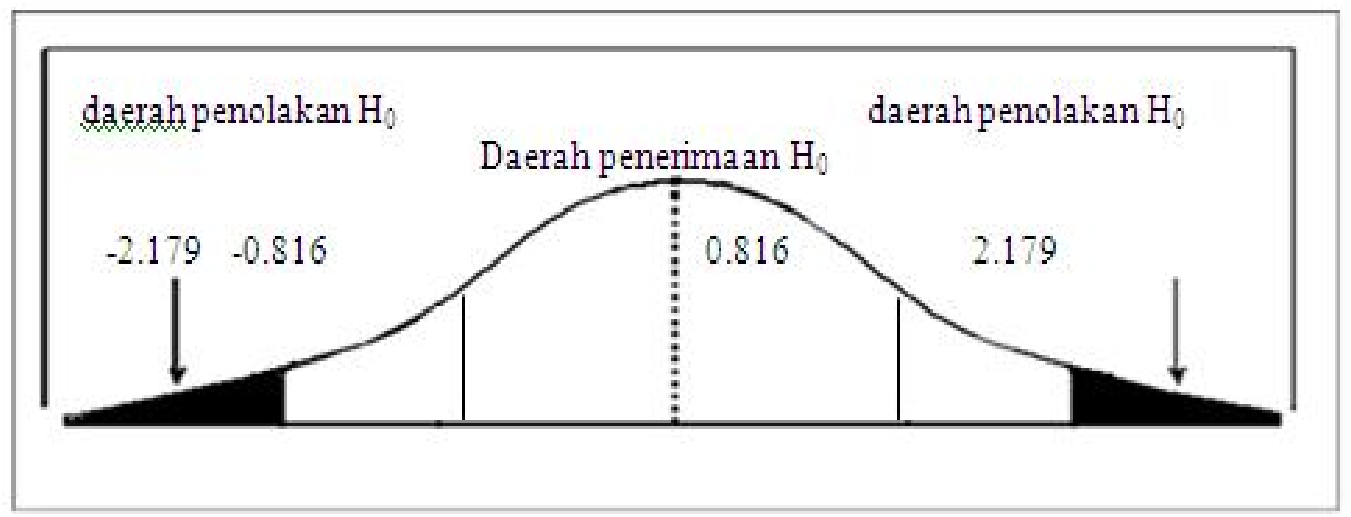

Gambar 3 Kurva Debt to Equity Ratio terhadap Harga Saham

\section{Uji Simultan (Uji F)}

Uji $\mathrm{F}$ atau uji global disebut juga uji signifikan serentak. Uji ini dimaksudkan untuk melihat kemampuan menyeluruh dari variabel independent yaitu $\operatorname{ROA}\left(\mathrm{X}_{1}\right)$ dan $\operatorname{DER}\left(\mathrm{X}_{2}\right)$ untuk dapat atau mampu menjelaskan harga saham (Y). Berdasarkan Tabel mengenai hasil perhitungan Return on Asset, Debt to Equity Ratio, dan Harga Saham perusahaan finansial periode 2004-2010 yang dianalisis dengan menggunakan program SPSS 16.0 diperoleh hasil uji f sebagai berikut. 
Tabel 4 Uji F

\begin{tabular}{|c|c|c|c|c|c|c|}
\hline & Model & Sum of Squares & Df & Mean Square & $\mathbf{F}$ & Sig. \\
\hline \multirow[t]{3}{*}{1} & Regression & 22723.028 & 2 & 11361.514 & .372 & $.697^{\mathrm{a}}$ \\
\hline & Residual & 335535.329 & 11 & 30503.212 & & \\
\hline & Total & 358258.357 & 13 & & & \\
\hline
\end{tabular}

a. Predictors: (Constant), der, roa

b. Dependent Variable: hs

Berdasarkan perhitungan dengan SPSS, diperoleh nilai $\mathrm{F}_{\text {hitung }}$ sebesar 0,372 sedangkan nilai $\mathrm{F}_{\text {tabel }}$ pada taraf $=5 \%$ dengan derajat pembilang $\mathrm{k}=2$ dan derajat penyebut digunakan $\mathrm{n}-\mathrm{k}-1=14-2-1=$ 11, maka diperoleh $\mathrm{F}_{\text {tabel }}$ sebesar 1,179. Hasil tersebut menunjukkan bahwa $\mathrm{F}_{\text {hitung }}<\mathrm{F}_{\text {tabel }}$ atau $0.372<$ 1,179 dan sig $>0,05$ yaitu $(0,697>0,05)$. Karena $\mathrm{F}_{\text {hitung }}<\mathrm{F}_{\text {tabel }}$ dan sig $>0,05, \mathrm{H}_{3}$ ditolak. Dengan demikian dapat disimpulkan bahwa ROA dan DER tidak terdapat pengaruh yang signifikan secara bersama-sama terhadap harga saham.

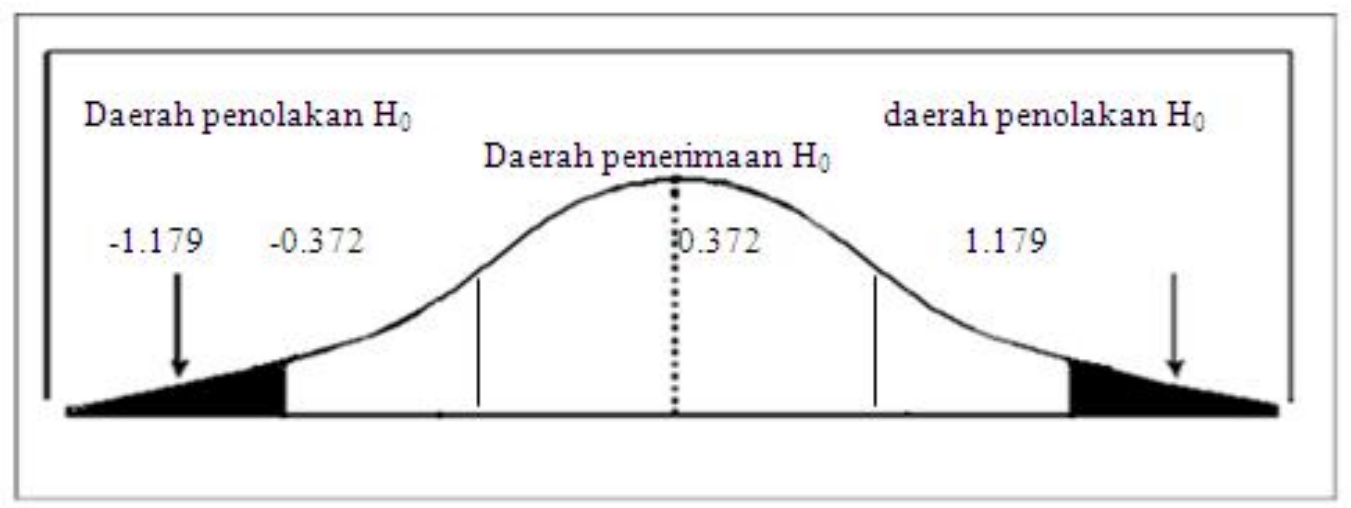

Gambar 4 Kurva ROA dan DER terhadap Harga Saham

\section{Analisis Koefisien Determinasi}

Koefisien determinasi digunakan untuk mengetahui kesesuaian atau ketepatan hubungan antara variabel independent dengan variabel dependent dalam persamaan regresi. Atau dengan kata lain, koefisien determinasi menunjukkan kemampuan variabel independent $(\mathrm{X})$ untuk menjelaskan variabel dependent ( $\mathrm{Y}$ ). Makin besar nilai koefisien determinasi, makin baik kemampuan variabel $\mathrm{X}$ menjelaskan variabel $\mathrm{Y}$. Koefisien Determinasi variabel return on asset $\left(\mathrm{X}_{1}\right)$ dan debt to equity ratio $\left(\mathrm{X}_{2}\right)$ terhadap harga saham $(\mathrm{Y})$ :

$$
\begin{aligned}
\mathrm{KD} & =\mathrm{R}^{2} \times 100 \% \\
& =\left(0,252^{2}\right) \mathrm{X} 100 \% \\
& =(0,063504) \times 100 \% \\
& =6,3504 \%
\end{aligned}
$$

Berdasarkan perhitungan, diperoleh nilai koefisien determinasi Return on Asset $\left(\mathrm{X}_{1}\right)$ dan Debt to Equity Ratio $\left(\mathrm{X}_{2}\right)$ sebesar 0,063504. Hal ini dapat diartikan bahwa Return on Asset $\left(\mathrm{X}_{1}\right)$ dan Debt to Equity Ratio $\left(\mathrm{X}_{2}\right)$ mampu menjelaskan 6,3504\% terhadap Harga Saham (Y) dan sisanya sebesar 93,6496\% dijelaskan oleh variabel lain yang tidak diteliti. 


\section{Pembahasan}

Berdasarkan hasil penelitian yang menguji pengaruh ROA dan DER terhadap Harga Saham pada institusi finansial periode 2004 - 2010, berikut adalah beberapa hal yang dapat dijelaskan dalam penelitian ini.

Perkembangan Return on Asset (ROA) pada Institusi Finansial pada periode 2004 -2010 juga mengalami peningkatan dan penurunan setiap tahunnya. Peningkatan dan penurunan ini terjadi karena harga saham tiap tahun mengalami fluktuasi yang sulit untuk diprediksi. Nilai tertinggi dari ROA adalah 0,088 , yaitu pada 2005. Hal ini disebabkan perusahaan mampu memprediksi kapan harga saham akan naik ataupun turun dan dapat meningkatkan nilai harga saham. Dengan begitu, perusahaan memiliki nilai ROA yang tinggi, sehingga para investor berminat untuk menginvestasikan modalnya dan harga saham akan meningkat. Sementara nilai terendah ROA adalah sebesar 0,042 yaitu tahun 2007.

Berdasarkan hasil pengujian hipotesis variabel Return on Asset secara parsial menunjukkan tidak berpengaruh terhadap Harga Saham. Hal ini dapat ditunjukkan dengan nilai $t_{\text {hitung }}<\mathrm{t}_{\text {tabel }}$ ($0,371<2,179)$, dengan demikian $\mathrm{H}_{01}$ diterima. Artinya, tidak terdapat pengaruh positif antara Return on Asset terhadap Harga Saham. Hal ini berarti tidak sesuai dengan hipotesis semula bahwa ROA mampu memengaruhi peningkatan harga saham. Hal ini sesuai dengan penelitiaan yang dilakukan oleh Stella (2009), Subiyantoro dan Andreani (2003) yang menyimpulkan bahwa Return on Asset tidak berpengaruh terhadap Harga Saham.

Debt to Equity Ratio (DER) pada Institusi Finansial dari 2004-2010 mengalami peningkatan dan penurunan tiap tahun. Peningkatan dan penurunan ini terjadi karena kebijakan dari manajemen perusahaan dalam hal keputusan jumlah kewajiban yang harus dibayarkan serta pengoptimalan nilai Debt to Equity Ratio (DER) untuk meningkatkan return perusahaan terhadap sahamnya. Nilai tertinggi dari Debt to Equity Ratio (DER) adalah 4,5787 pada 2008. Sedangkan nilai terendah dari Debt to Equity Ratio (DER) adalah sebesar 0.3501 pada 2009. Hal ini diakibatkan perusahaan telah mampu menggunakan modal sendiri dan total utang dari pinjaman untuk kegiatan operasional perusahaan, ekspansi, peningkatan produktivitas dan lain-lain secara efektif dan efisien. Oleh karena itu perusahaan dapat memperoleh tingkat pengembalian (return) yang tinggi.

Berdasarkan hasil penelitian pada Institusi Finansial, Debt to Equity Ratio (DER) memiliki nilai koefisien parsial sebesar $-0,816$. Hal ini dapat diartikan bahwa hubungan antara DER dengan Harga saham negatif sangat rendah. Artinya jika DER naik, harga saham akan turun; begitu juga sebaliknya jika DER turun, harga saham akan naik. Sedangkan uji signifikansi antara DER dengan harga saham ditunjukkan dengan nilai (sig. 2-tailed $>0.05$ atau $\alpha<0.05$ ), yang berarti terdapat hubungan yang signifikan antara DER dengan harga saham. Maka, $\mathrm{H}_{02}$ ditolak dan tidak memiliki pengaruh antara Debt to Equity Ratio terhadap harga saham. Hasil ini sesuai dengan penelitian yang dilakukan Subiyantoro dan Andreani (2003), bahwa DER tidak memiliki pengaruh terhadap harga saham. Harga saham adalah sama dengan nilai tunai atau present value dari keuntungan pada masa yang akan datang. Harga saham pada institusi finansial dari tahun ke tahun mengalami peningkatan dan penurunan. Peningkatan dan penurunan ini disebabkan harga saham (closing price) perusahaan yang dibagikan kepada para pemegang saham mengalami fluktuasi setiap tahun. Nilai tertinggi harga saham adalah Rp660,00 pada 2010 dan nilai terendah harga saham adalah sebesar Rp113,00 pada 2008.

Setelah dilakukan perhitungan, diperoleh hasil persamaan regresi antara Return on Asset dan Debt to Equity Ratio terhadap Harga Saham adalah Y= 475,411 - 1876,520 ROA - 35,804 DER. Nilai intercept (konstanta atau a) sebesar 475,411 menunjukkan nilai Harga Saham jika ROA $\left(\mathrm{X}_{1}\right)$ dan DER $\left(\mathrm{X}_{2}\right)$ dianggap nol. Nilai b1 sebesar -1876,520 menunjukkan koefisien regresi X1 (ROA) terhadap Harga Saham (Y), jika X2 (DER) dianggap konstan. Nilainya negatif, maka setiap penaikan ROA 
sebesar 1\% akan menurunkan harga saham sebesar Rp1876,520. Begitu juga sebaliknya, setiap penurunan ROA sebesar 1\%, maka akan menaikkan harga saham sebesar Rp1876,520. Nilai $\mathrm{b}_{2}$ sebesar -35,804 menujukkan koefisien regresi X2 (DER) terhadap Harga Saham (Y), jika X1 (ROA) dianggap konstan. Karena nilainya negatif, setiap penurunan DER sebesar 1\% akan menaikkan harga saham sebesar Rp35.804. Begitu juga sebaliknya, setiap kenaikkan DER sebesar 1\% akan menurunkan harga saham sebesar Rp35,804.

Berdasarkan hasil uji simultan (uji F) antara ROA, DER terhadap Harga saham diperoleh nilai $\mathrm{F}_{\text {hitung }}$ sebesar 0,372 sedangkan nilai $\mathrm{F}_{\text {tabel }}$ pada taraf $=5 \%$ dengan derajat pembilang $\mathrm{k}=2$ dan derajat penyebut digunakan n-k-1 = 14-2-1 = 11, maka diperoleh $\mathrm{F}_{\text {tabel }}$ sebesar 1,179. Hasil tersebut menunjukkan bahwa $\mathrm{F}_{\text {hitung }}<\mathrm{F}_{\text {tabel }}$ atau $0,372<1,179$ dan sig $<0,05$ yaitu $(0,697>0,05)$. Karena $\mathrm{F}_{\text {hitung }}<\mathrm{F}_{\text {tabel }}$ dan sig $>0,05, \mathrm{H}_{3}$ ditolak. Dapat ditarik kesimpulan bahwa ROA dan DER tidak terdapat pengaruh yang signifikan secara bersama-sama terhadap harga saham.

\section{SIMPULAN}

Berdasarkan hasil analisis data dan pembahasan tentang Return On Asset dan Debt to Equity Ratio terhadap Harga Saham pada perusahaan yang bergerak di bidang finansial yang terdaftar di Bursa Efek Indonesia (BEI) selama periode penelitian tujuh tahun (2004-2010), maka dapat diambil beberapa simpulan sebagai berikut. Pertama, Return on Asset tidak memiliki pengaruh yang signifikan terhadap Harga Saham. Berdasarkan hasil perhitungan $t$-test diperoleh $t_{\text {hitung }}(-0,371)<t_{\text {tabel }}(-2,179)$. Kedua, Debt to Equity Ratio tidak memiliki pengaruh signifikan terhadap Harga Saham. Berdasarkan hasil pengujian $\mathrm{t}$-test diperoleh $\mathrm{t}_{\text {hitung }}(-0,816)<\mathrm{t}_{\text {tabel }}(-2,179)$. Kedua, dari pengujian regresi dengan melihat tabel Anova, jika diuji secara simultan, Return on Asset dan Debt to Equity Ratio secara bersama-sama berpengaruh terhadap Harga Saham.

\section{DAFTAR PUSTAKA}

Anastasia, N. (2003). Analisis faktor fundamental dan risiko sistematik terhadap harga saham properti di BEJ. Jurnal Akuntansi dan Keuangan, 5(2), 123-132.

Dendawijaya, L. (2003). Manajemen Perbankan. Jakarta: Ghalia Indonesia.

Ferdinand, A. (2011). Metode Penelitian Manajemen. Semarang: Indoprint.

Ghozali, I. (2006). Aplikasi Analisis Multivariate dengan Program SPSS. Semarang: Badan Penerbit Universitas Diponegoro.

Harahap, S. S. (2010). Analisis Kritis atas Laporan Keuangan. Jakarta: Raja Grafindo Persada.

Hasan, M. I. (2005). Pokok-pokok Materi Statistik 1 (Statistik Deskriptif). Jakarta: Bumi Aksara.

Kasmir. (2008). Bank dan Lembaga Keuangan Lainnya. Jakarta: Raja Grafindo Persada.

Kusumawardani, A. (2010). Analisis Pengaruh EPS, DER, ROE, FL, CR, dan ROA terhadap Harga Saham. Universitas Gunadarma. 
Lestari, M. I. \& Sugiharto, T. (2007). Kinerja bank devisa dan bank non devisa dan faktor-faktor yang mempengaruhinya. Proceeding PESAT (Psikologi, Ekonomi, Sastra, Arsitek \& Sipil), 2. Fakultas Ekonomi, Universitas Gunadarma.

Mardiyanto, H. (2009). Intisari Manajemen Keuangan. Jakarta: Grasindo.

Rinati, I. \& Budiman. (2009). Pengaruh Net Profit Margin, Return On Assets, dan Return On Equity terhadap Harga Saham pada Perusahaan yang Tercantum dalam Indeks LQ45. Jakarta: Universitas Gunadarma.

Riyadi, S. (2006). Banking Assets and Liability Management. Edisi 3. Jakarta: Lembaga Penerbit Fakultas Ekonomi Universitas Indonesia.

Rusdin. (2008). Pasar Modal: Teori, Masalah dan Kebijakan dalam Praktik. Bandung: Alfabeta.

Sasongko, Noer dan Nila Wulandari. 2006. Pengaruh EVA dan rasio-rasio profitabilitas terhadap harga saham. Empirika, 19(1), 64-80.

Stella. (2009). Pengaruh PER, DER, ROA dan PBV terhadap Harga Pasar Saham.” Jurnal Bisnis dan Akuntansi, 11(2), 97-106.

Subiyantoro, E. \& Andreani, F. (2003). Analisis faktor-faktor yang memengaruhi harga saham. Jurnal Manajemen \& Kewirausahaan, 5(2), 171-180.

Umar, H. (2004). Manajemen Riset Pemasaran dan Perilaku Konsumen. Jakarta: Gramedia Pusaka.

Weston, J. F. \& Copeland, T. E. (1999). Manajemen Keuangan. Edisi 8. Jakarta: Bina Rupa Aksara

Wulandari, D. A. (2009). Analisis faktor fundamental terhadap harga saham. Jurnal Akuntansi \& Keuangan, Oktober. 